\title{
THE RELATION BETWEEN THE BIOLOGICAL ACTIVITY AND THE LAND SURFACE TEMPERATURE IN BUDAPEST
}

\author{
P. GÁBOR ${ }^{1 *}-$ S. JOMBACH ${ }^{2}$ \\ ${ }^{1}$ Greentree Studio Ltd., Petneházy út 31., Budapest, Hungary. \\ ${ }^{2}$ Corvinus University of Budapest, Villányi út 35-43, Budapest, Hungary. \\ sandor.jombach@uni-corvinus.hu \\ *Corresponding author \\ e-mail: office@greentree.hu \\ (Received $2^{\text {nd }}$ October $2009 ;$ accepted $2^{\text {nd }}$ November 2009)
}

\begin{abstract}
The aim of our investigation was to study in detail the relationship between the spatial structure of the urban green surface and land surface temperatures. The research was carried out to support the elaboration of the Environmental Action Programme of Budapest (Hungary) focusing on city planning as well. The ultimate goal was the utilization of the findings to provide planning guidance for the city, on how vegetation could contribute to the mitigation of the negative effects of urban heat island in more effective ways.

Keywords: Green surface, land surface temperature, satellite image, land use, urban heat island, human comfort, vegetation, remote sensing
\end{abstract}

\section{Introduction}

Analysing the Landsat5 TM satellite image of Budapest we found strong negative correlation between land surface thermal radiation and biological activity of vegetation. In order to present this correlation for the general public we created cross section diagrams of Budapest, which simultaneously present the land surface temperature and values of a vegetation index (NDVI). In accordance with the city's zoning plan we analyzed the land surface temperature and vegetation characteristics of 14 land use types. The difference between the mean temperature of these land use types exceeded $15^{\circ} \mathrm{C}$. The land use types of highest land surface temperature values were road and railway junctions, commercial areas (shopping centres), manufacturing sites and high density residential areas. Our suggestion is, that these are the land use types which are chiefly responsible for the creation of the urban heat island.

Utilising the findings of the survey our team made several policy recommendations, which form part of the Budapest Environmental Program 2007.

\section{Review of Literature}

\section{The effect of urban heat island on human comfort}

The high building density, the lack of surfaces allowing evaporation and increasing human activity change the energy and water balance of the land surface and the atmosphere in urbanised environments. This results in the creation of the phenomenon of urban heat islands (UHI), which are the areas of excess warmth of the urban atmosphere and surfaces compared to their rural surroundings [19]. There is a great 
number of surveys describing the characteristics and effects of the UHI. Oke's study of 1987 described the changed temperature, moisture and aerodynamic conditions of urbanized areas [16]. There is a difference between atmospheric UHI and land surface UHI. The former has its highest level in the early evening hours, while the latter around the mid day period. [10] The annual characteristics of the UHI vary regionally. For instance while South-East Asian surveys suggest that the annual maximum values of the UHI are in the autumn and winter period [14, 26], a survey of 8 Asian mega cities suggest that in the North Hemisphere the maximum in August, in tropical cities in the dry season [10], while surveys in Hungary demonstrate the maximum values are in June and July [1]. The easier access to satellite images and the improvement of GIS technologies contributed to the increased number of studies. Images of NOAA [6] of Terra and Aqua [1, 10] and of Landsat [19, 23] area also used for UHI related analysis. Because of the effects of UHI the energy demand for cooling of buildings increases [15]. Different land use types have different effects on UHI. Using remote sensing data and GIS analysis, studies try to reveal these effects. (For literature review see [13].) It is suggested that the UHI has a significant effect on the regional climate and also on socioeconomic development [3]. In our paper we would like to emphasize that it frequently has a more noticeable local effect, since it can significantly deteriorate the value of human comfort indices of open spaces in urbanized areas.

\section{Human comfort and the mitigation of urban heat island effects}

One might think that the thermal environment of the human body is chiefly determined by the air temperature. If the air temperature is too low we are cold, if it is too high we are hot, if neither then we feel comfortable. A study suggests that there are three other factors to be taken in consideration: relative humidity, wind speed and surface radiation [8]. The combination of these four determine the evaporation of the human body, and hence thermal comfort. During the summer period the most significant input in the thermal indices is not the air temperature, but the mean radiant temperature [9]. This suggests that the land surface temperature studied in this research has a very significant effect on the comfort conditions of open spaces.

Research suggests, that there are six main strategies of how the negative effects of UHI can be mitigated [2]: a) modification of urban geometry, b) use of light-coloured surfaces, c) policies and measures to increase energy efficiency, d) management of traffic and better transportation system design, e) use of permeable surfaces, f) use of vegetated surfaces. In our research we study how the presence or the absence of urban greenery in Budapest effects the Land Surface Temperature (LST) and hence the UHI of the city.

\section{Methods}

\section{The relation between vegetation and thermal radiation of land surface}

It is a well known and documented fact that the land surface temperature and the vegetation are related to each other. Some studies focus on the description of how urbanization process, and the loss of vegetation contribute to rising urban temperatures [13], while others focus on how vegetation can reduce the negative effects of the UHI [21]. Multispectral satellite images make possible the measurement of both the vegetation and the thermal radiation at regional scale. Several indexes are derived from 
satellite images which can be used to describe the urban vegetation, such as the Normalized Difference Water Index (NDWI) [7] or the Normalized difference built-up Index (NDBI) [25]. The most frequently used index to measure vegetation is the Normalised Difference Vegetation Index (NDVI), derived form the red and infrared channels of satellite images [24].

In our research, analysing the Landsat5 TM satellite image, we intended to investigate the relation between NDVI and Thermal Radiation (TR) values in the case of Budapest. The 25-120 m resolution of the image allowed us to analyse urban vegetation and the UHI in greater details than was done so far in Hungary [1]. We used the vegetation index (NDVI) as an index of green surface intensity (vegetation cover) since in our previous studies we have found strong correlation between them [4, 12]. The analysed satellite image was taken on the 1st of August 2005 at 9:30 AM (CET), which was a clear and sunny day. The air temperature at 9:30 was $24,3{ }^{\circ} \mathrm{C}$, while the daily maximum was $31{ }^{\circ} \mathrm{C}$ at $16: 30$, hence the radiation values of the image do not present the daily peak values.

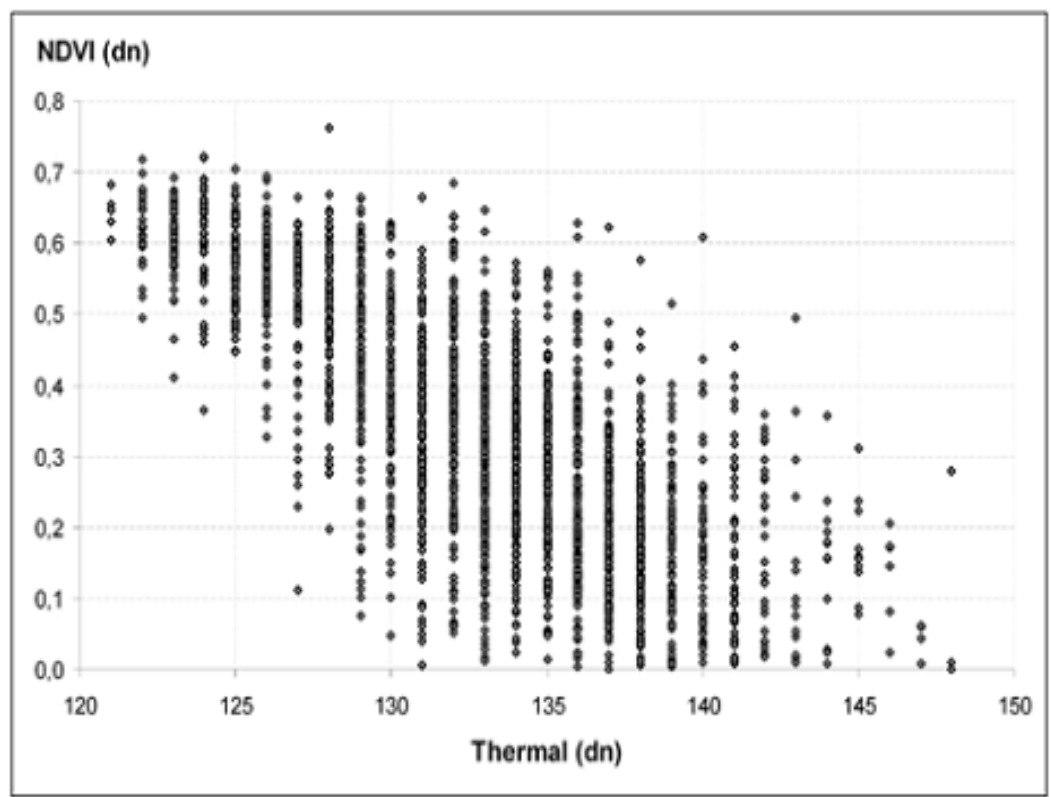

Figure 1. Relationship between biological activity of vegetation and thermal values of land surface in Budapest. (Represented by positive NDVI values and values of thermal infra band Landsat5 TM satellite image in the 1st of August 2005 9:00 CET)

The relation between the positive NDVI values and the TR variables were tested by seven different correlation analyses. The value of the square of the correlation coefficient $\left(R^{2}\right)$ in the case of linear regression was 0.588 . The value of the $R^{2}$ was slightly better in the case of Quadratic $(0,603)$ and Cubic $(0,604)$ correlation. The value of the constant was negative in all cases. These results suggest that there is significant negative correlation between Normalised Differential Vegetation Index and the TR values of the satellite image. (Fig. 1.) However the correlation is not strong enough to make it possible to calculate the TR directly from the NDVI value of a designated spot. (Table 1.) 
Table 1. Correlation between vegetation biological activity (NDVI) and land surface thermal radiation (TR) values derived from satellite image (Landsat5 TM)

\begin{tabular}{|c|c|c|c|c|c|c|c|c|c|}
\hline \multirow{2}{*}{ Equation } & \multicolumn{6}{|c|}{ Model Summary } & \multicolumn{3}{|c|}{ Parameter Estimates } \\
\hline & R2 & $\mathrm{F}$ & df1 & $\mathrm{df} 2$ & Sig. & Const. & $\mathrm{b} 1$ & b2 & b3 \\
\hline Linear* & 0,588 & 2638,38 & 1848 & 0,000 & 140,082 & $-21,455$ & & & 0,588 \\
\hline Quadratic** & 0,603 & 1401,51 & 1847 & 0,000 & 138,562 & $-8,9969$ & $-18,475$ & & 0,603 \\
\hline Cubic**** & 0,604 & 937,77 & 1846 & 0,000 & 139,033 & $-16,41$ & 8,6186 & $-26,727$ & 0,604 \\
\hline Exponential $* * * * *$ & 0,592 & 2680,46 & 1848 & 0,000 & 140,224 & $-0,1624$ & & & 0,592 \\
\hline
\end{tabular}

Independent variable: NDVI, Dependent variable TR

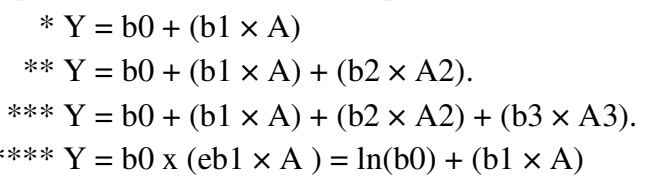

\section{Retrieving Land Surface Temperature}

It was important to estimate the Land Surface Temperature (LST) from the satellite image in order to facilitate understanding of TR easier and relate to Celsius temperature scale. There are two main methods of retrieving LST using the data basically of the $6^{\text {th }}$, and additionally the $3^{\text {rd }}$ and $4^{\text {th }}$ band of Landsat TM5 satellite image. One of these is the "Mono Window Algorithm" [18], the other is the "Single Channel Method" [11]. Using the LST software [22] we have calculated the land surface temperature both by using the mono window algorithm developed by Qin et al and the single-channel algorithm developed by Jimenez-Munoz. The publications describe both methods with approximately $2{ }^{\circ} \mathrm{C}$ accuracy. [20]. We generated the LST for our purpose by calculating the average values of the two model outputs. The meteorological data required for the calculations (atmospheric transmittance, effective mean atmospheric temperature, total atmospheric water vapour) were provided by the National Meteorological Institute of Hungary (OMSZ).

\section{Results}

\section{Analysing the cross sections of Budapest}

Using NDVI values, representing green surface intensity as well, and LST variables we created cross section diagrams of Budapest. It was found that these diagrams make it easier to understand the correlation between vegetation and LST for the general public and also for decision makers. Using the diagram the results of the analysis of the thermal and vegetation biological activity of a given location are more evident, which was the basic for the research team to form policy recommendations.

The diagrams present the Northwest-Southeast and Southwest-Northeast cross sections of Budapest, with well recognisable inverse tendencies of the biological activity of vegetation and LST. The increasing values of biological activity result in the decrease of thermal values and vice versa. This tendency can be recognised for each area where significant differences between NDVI values exist. The only exception being the Danube river where the 0 NDVI values are met with equally low LST values. In this case the cooling effect of the water surface results in low LST values. (Fig. 2.) 


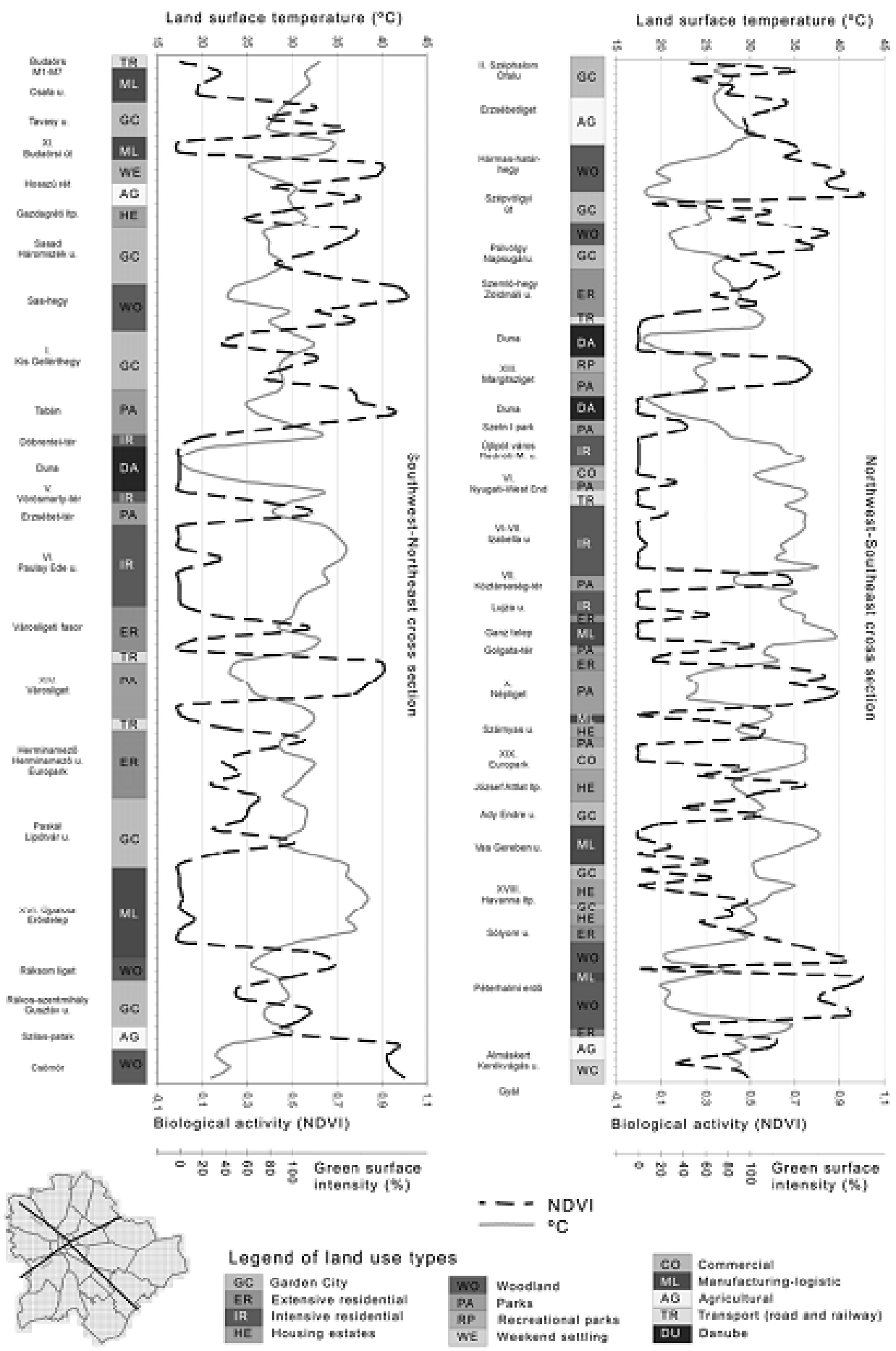

Figure 2. Diagram of cross sections in Budapest demonstrating green surface intensity (NDVI) and land surface temperature $\left({ }^{\circ} \mathrm{C}\right)$ connection with regard to land use types as well.

The maps, based on interpreted satellite images, show that e.g. in the Margit-sziget (Margaret Island), one of the major parks of the city, the intensive vegetation causes low LST values $\left(18,5-24,0^{\circ} \mathrm{C}\right)$. At the intensive residential area of the East side of the 
river in Újlipótváros one can mainly find low vegetation values and high surface temperatures (NDVI 0, means actually no green surface at all; LST 33,0-36,0 ${ }^{\circ} \mathrm{C}$ ) except of patches of smaller parks, gardens and squares of high green surface intensity (e.g. Szent István park, Honvéd tér, Kossuth tér). The roof garden of the West End shopping centre definitely reduces the LST values by a few degrees Celsius $\left(30,5-32,5^{\circ} \mathrm{C}\right)$, which is in great contrast with the neighbouring railway area (LST $36,0^{\circ} \mathrm{C}$ ). (Fig. 3.)

\begin{tabular}{|c|c|c|}
\hline & NDVI & $\begin{array}{c}\text { Green surface } \\
\text { intensity }\end{array}$ \\
\hline & above 0,5 & $100 \%$ green surface \\
\hline & $0,45 \cdot 0,5$ & $90 \cdot 99,9 \%$ \\
\hline & $0,4 \cdot 0,45$ & $80-90 \%$ \\
\hline & $0,35 \cdot 0,4$ & $70 \cdot 80 \%$ \\
\hline & $0,3 \cdot 0,35$ & $60 \cdot 70 \%$ \\
\hline & $0,25 \cdot 0,3$ & $50 \cdot 60 \%$ \\
\hline & $0,2 \cdot 0,25$ & $40 \cdot 50 \%$ \\
\hline & $0,15 \cdot 0,2$ & $30.40 \%$ \\
\hline & $0,1 \cdot 0,15$ & $20 \cdot 30 \%$ \\
\hline & $0,05 \cdot 0,1$ & $10 \cdot 20 \%$ \\
\hline & $0.0,05$ & $0,1 \cdot 10 \%$ \\
\hline & under 0 & No green surface \\
\hline \multicolumn{3}{|c|}{ Water surface } \\
\hline \multicolumn{3}{|c|}{ Road network } \\
\hline
\end{tabular}
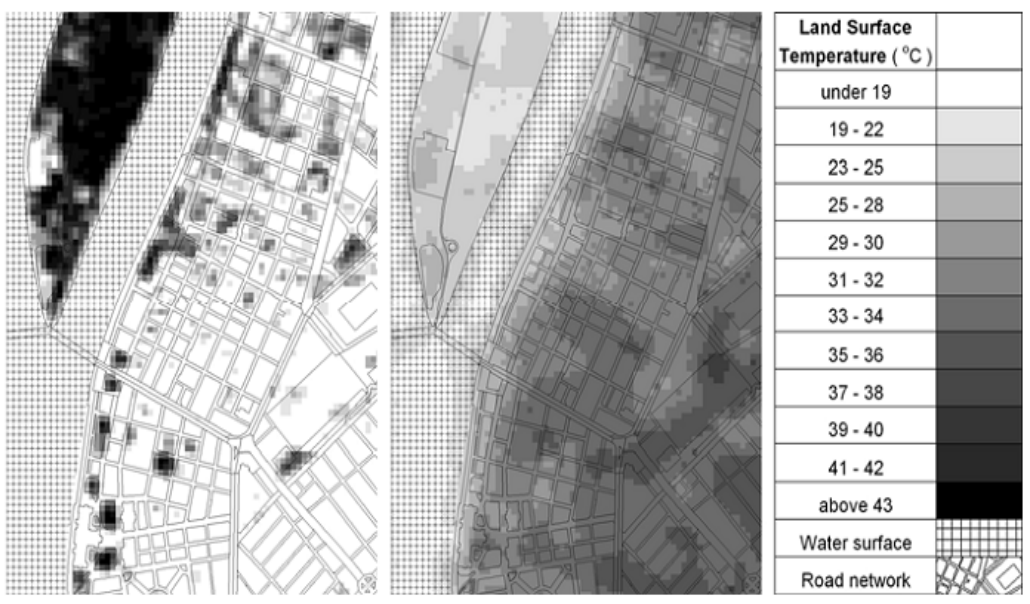

Figure 3. Map of green surface intensity (based on NDVI) and land surface temperature $\left({ }^{\circ} \mathrm{C}\right)$. Margaret Island and Újlipótváros.

It is noticeable that compared to densely built intensive residential areas, the extensive residential area along the Városligeti fasor (City Park alley) with higher green surface intensity $(32-100 \%)$, results in lower land surface temperatures $\left(28-30^{\circ} \mathrm{C}\right)$. It is remarkable that the high temperature of the Hungária Ring $\left(32,5-31,5^{\circ} \mathrm{C}\right)$ is in strong contrast with the adjoining Városliget (City Park) (NDVI 0,3-0,9 mainly 60-100\% green surface; LST 23,0-26,0 ${ }^{\circ} \mathrm{C}$ ). (Fig. 4.)

\begin{tabular}{|c|c|c|}
\hline & NDVI & $\begin{array}{c}\text { Green surface } \\
\text { intensity }\end{array}$ \\
\hline & above 0,5 & $100 \%$ green surface \\
\hline & $0,45 \cdot 0,5$ & $90 \cdot 99,9 \%$ \\
\hline & $0,4 \cdot 0,45$ & $80.90 \%$ \\
\hline & $0,35 \cdot 0,4$ & $70 \cdot 80 \%$ \\
\hline & $0,3 \cdot 0,35$ & $60 \cdot 70 \%$ \\
\hline & $0,25 \cdot 0,3$ & $50 \cdot 60 \%$ \\
\hline & $0,2 \cdot 0,25$ & $40 \cdot 50 \%$ \\
\hline & $0,15 \cdot 0,2$ & $30.40 \%$ \\
\hline & $0,1 \cdot 0,15$ & $20 \cdot 30 \%$ \\
\hline & $0,05 \cdot 0,1$ & $10 \cdot 20 \%$ \\
\hline & $0.0,05$ & $0,1 \cdot 10 \%$ \\
\hline & under 0 & No green surface \\
\hline \multicolumn{3}{|c|}{ Water surface } \\
\hline \multicolumn{3}{|c|}{ Road network } \\
\hline
\end{tabular}
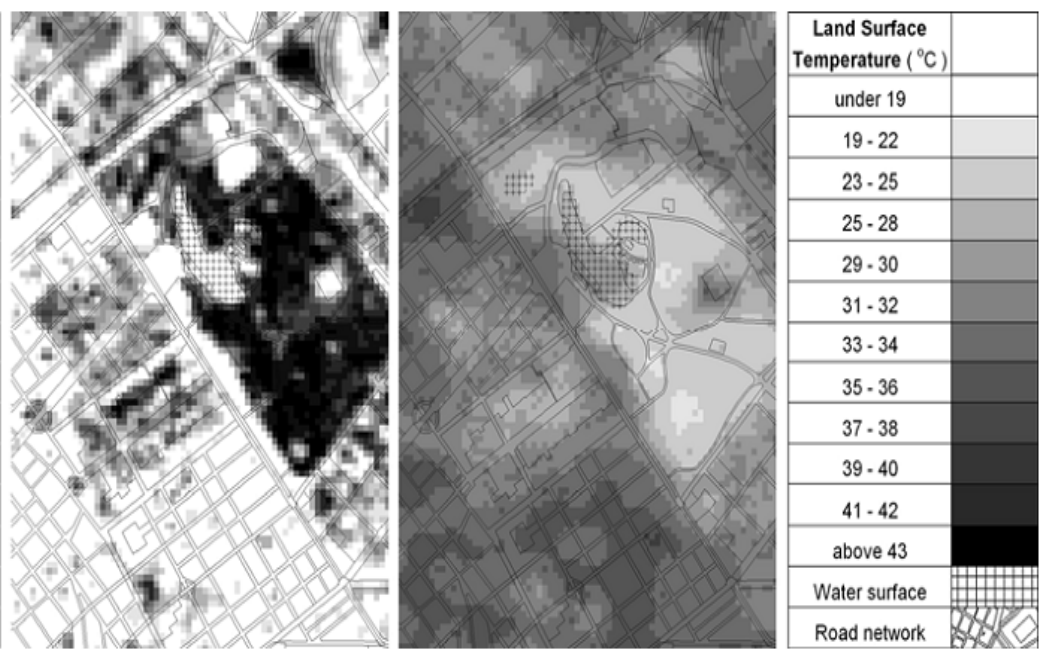

Figure 4. Map of green surface intensity (based on NDVI) and land surface temperature $\left({ }^{\circ} \mathrm{C}\right)$. The City Park and the City Park alley in Budapest. 


\section{Analysing land use types}

In the next stage of the research we examined how the different urban land use types can be characterised both by vegetation and thermal values. According to the city zoning plan we differentiated 14 land use types, in four groups such as residential, economic, recreation and transport. We examined 95 sample areas covering a total of 3300 hectares (over $6 \%$ of the city area). Calculating the mean value, the standard deviation and the lowest and highest NDVI and the LST values of the pixels we described the characteristics of these land uses (Table 2.).

Table 2. Land use types with vegetation and land surface temperature characteristics

\begin{tabular}{|c|c|c|c|c|c|c|c|c|}
\hline \multirow[t]{2}{*}{$\begin{array}{c}\text { Land use } \\
\text { types }\end{array}$} & \multicolumn{2}{|c|}{ Sample area } & \multicolumn{3}{|c|}{ NDVI } & \multicolumn{3}{|c|}{ LST $\left({ }^{\circ} \mathrm{C}\right)$} \\
\hline & $\begin{array}{l}\text { sample } \\
\text { number }\end{array}$ & size ha & mean & $\begin{array}{c}\text { standard } \\
\text { deviation }\end{array}$ & $\begin{array}{l}\max . \\
\text { value }\end{array}$ & mean & $\begin{array}{c}\text { standard } \\
\text { deviation }\end{array}$ & $\begin{array}{l}\max . \\
\text { value }\end{array}$ \\
\hline \multicolumn{9}{|c|}{ RESIDENTIAL GROUP } \\
\hline $\begin{array}{l}\text { Intensive } \\
\text { residential }\end{array}$ & 5 & 53 & 0,02 & 0,05 & 0,45 & 33,92 & 1,47 & 37,00 \\
\hline $\begin{array}{l}\text { Extensive } \\
\text { residential }\end{array}$ & 6 & 120 & 0,27 & 0,12 & 0,61 & 28,35 & 2,14 & 34,50 \\
\hline Garden city & 10 & 288 & 0,22 & 0,09 & 0,55 & 29,79 & 1,92 & 35,50 \\
\hline Housing estates & 9 & 232 & 0,19 & 0,11 & 0,56 & 30,48 & 1,53 & 36,00 \\
\hline \multicolumn{9}{|c|}{ ECONOMIC GROUP } \\
\hline $\begin{array}{l}\text { Manufacturing- } \\
\text { logistic }\end{array}$ & 6 & 270 & 0,05 & 0,08 & 0,59 & 34,87 & 2,76 & 43,50 \\
\hline Commercial & 4 & 47 & 0,03 & 0,07 & 0,44 & 35,30 & 3,28 & 44,00 \\
\hline Agricultural & 13 & 596 & 0,34 & 0,21 & 0,70 & 27,59 & 5,37 & 41,50 \\
\hline \multicolumn{9}{|c|}{ RECREATION GROUP } \\
\hline City parks & 4 & 258 & 0,40 & 0,16 & 0,64 & 25,15 & 2,65 & 36,50 \\
\hline Smaller parks & 9 & 51 & 0,35 & 0,17 & 0,65 & 28,20 & 3,14 & 38,00 \\
\hline Cemetery & 2 & 68 & 0,40 & 0,13 & 0,65 & 26,62 & 2,39 & 34,00 \\
\hline Recreational parks & 3 & 29 & 0,35 & 0,18 & 0,63 & 24,94 & 2,11 & 33,00 \\
\hline Woodland & 11 & 1207 & 0,59 & 0,10 & 0,85 & 20,58 & 2,45 & 33,00 \\
\hline \multicolumn{9}{|c|}{ TRANSPORT GROUP } \\
\hline Railway junctions & 5 & 70 & 0,03 & 0,08 & 0,42 & 35,51 & 1,42 & 39,00 \\
\hline Road junctions & 8 & 18 & 0,01 & 0,04 & 0,33 & 33,53 & 1,13 & 30,50 \\
\hline $\begin{array}{l}\text { Sum } \\
\text { Average }\end{array}$ & 95 & 3307 & 0,23 & 0,11 & 0,58 & 29,63 & 2,41 & 36,86 \\
\hline
\end{tabular}

Amongst residential land use types the highest mean LST $\left(33,9^{\circ} \mathrm{C}\right)$ and the lowest NDVI mean value $(0,22$ which is approximately $44 \%$ green surface intensity) can be found in the intensive residential areas, whilst the lowest thermal values and the highest green surface intensity characterize the extensive residential areas (LST 28, $3^{\circ} \mathrm{C}$; NDVI 0,27 means around $54 \%$ green surface intensity). We found that the zones of garden city and housing estates have similar thermal and vegetation characteristic in Budapest, and 
that their LST intensity is surprisingly a bit higher than that of the extensive residential areas. (Fig. 5.)

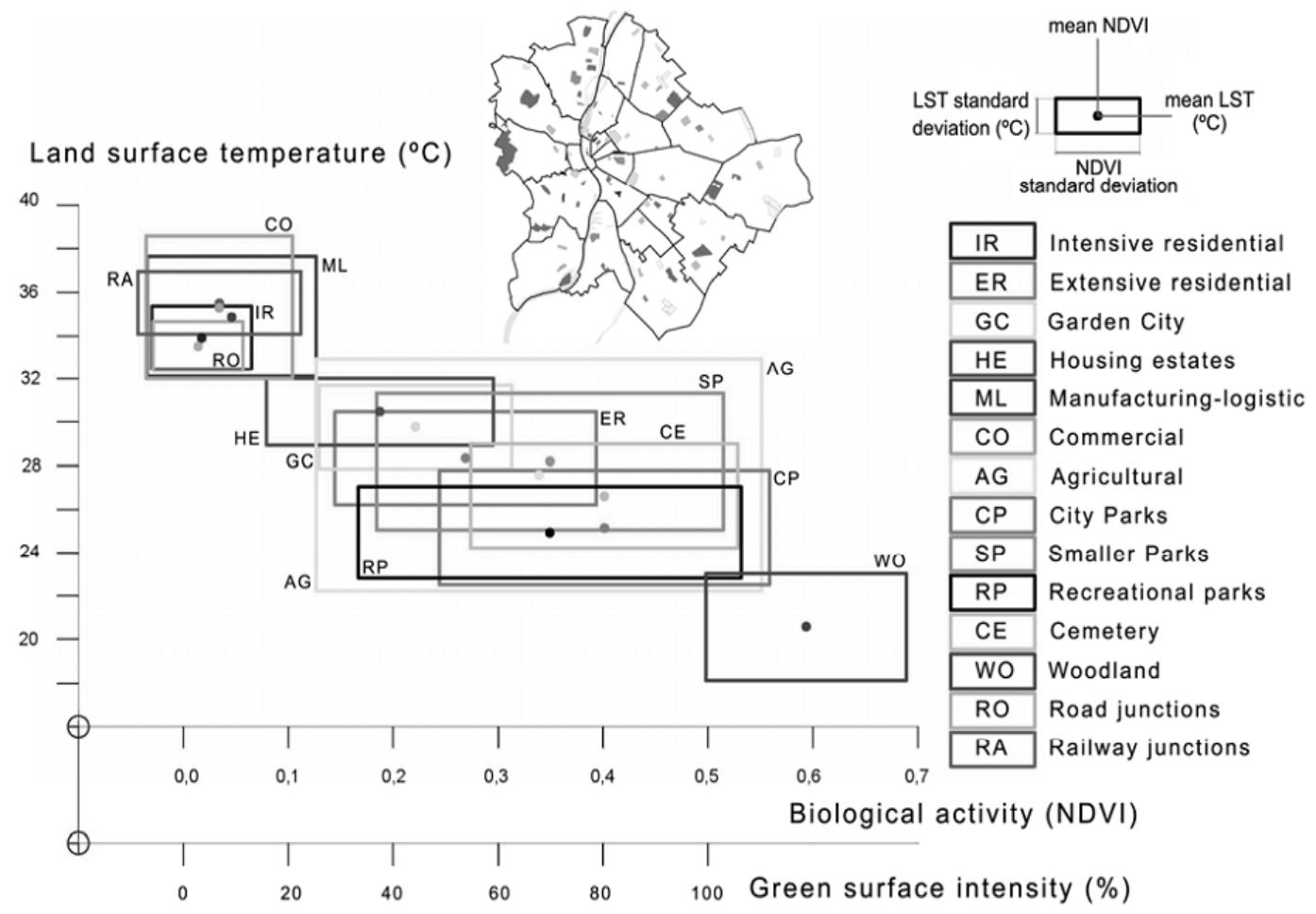

Figure 5. Diagram of sample area study results (see map of samples in Budapest on the top).

The 14 different land use types investigated in Budapest are characterised by the mean and standard deviation values of land surface temperature and biological activity.

In the economic group of land use types the highest maximal temperatures were found at commercial and manufacturing-logistic areas $\left(43,5-44,0{ }^{\circ} \mathrm{C}\right)$, which can partly be explained by the low NDVI values (0,07-0,08 14-16\% green surface intensity), but the thermal effects of manufacture and the intensive radiation of asphalt surfaces are likely to also be responsible for the high LST values. It is an unexpected finding, that in Budapest the commercial areas have lower mean NDVI value and higher mean LST than the manufacturing-logistic areas. Agricultural areas have higher vegetation and lower thermal values than the types belonging to the previous economic group (LST $27,6{ }^{\circ} \mathrm{C}$; NDVI 0,34 means $68 \%$ green surface intensity). However their most specific character is the high deviation both in vegetation and thermal values, which is not surprising, since the arable land, which mainly covers agricultural type in Budapest, can completely lack vegetation or may also have $100 \%$ plant coverage depending on the cultivation. The thermal standard deviation of manufacturing-logistic and commercial areas is also high, which suggest that the thermal characteristic of economic group land use types is not homogenous at all.

Within recreational group the lowest LST mean values $\left(20,6^{\circ} \mathrm{C}\right)$ and also the lowest standard deviation values $\left(0,10^{\circ} \mathrm{C}\right)$ were found at woodland which typically have $100 \%$ vegetation coverage. The recreational parks (outdoor swimming pools and spas) have very low LST values despite the relatively higher rate of built up areas within them (LST $24,9^{\circ} \mathrm{C}$, NDVI 0,35 means only $70 \%$ green surface intensity), which is probably 
due to the cooling effect of water surface. Amongst recreation types with the highest LST values $\left(28,2^{\circ} \mathrm{C}\right)$ are the parks of smaller size. The high standard deviation rate of the thermal values is also noticeable at these areas, which suggests that their thermal condition varies not solely according to their vegetation, but also other factors (e.g. the type and extent of paved surfaces within the park).

Among the examined sample areas the railway junction areas had the highest mean LST values $(35,5 \mathrm{C})$. The low vegetation at these areas (NDVI 0,08 means $16 \%$ green surface intensity) is not capable to reduce the high heat values. The road junctions were the areas of lowest vegetation intensity (NDVI 0,01 means $2 \%$ green surface intensity), which reflects that the low vegetation cover of these areas also contributes to the creation of the UHI.

\section{Discussion}

\section{Findings}

The UHI, prevailing during summer in continental climate, has a significant negative impact on the thermal comfort level of the citizens. Hence its reduction is important to create a better urban environment. As a result of our research we have showed that the manufacturing-logistic, commercial, intensive residential, railway and road junction areas are chiefly responsible for the creation of the UHI. This becomes highly important when results from a previous study about the change of biological activity in Budapest based on more satellite images are taken into account. This former study showed that two of these five land use types (commercial areas, road junctions) were definitely increasing, and green surface was slightly decreasing in the period between 1990 and $2005[5]$.

The most important findings of our research:

1. Biological activity and land surface temperature are in strong negative correlation. The vegetation index (surface cover) is on average low in the land use types with the highest LST.

2. The highest land surface temperatures can be found at manufacturing-logistic, commercial, intensive residential land uses and at railway and road junctions. It is suggested that these areas are mainly responsible for the Urban Heat Island.

3. The difference in land surface temperature at 9:30 CET in $1^{\text {st }}$ of August 2005 exceeded $25^{\circ} \mathrm{C}$.

4. The difference in the average temperature of the examined land use types exceeded $14^{\circ} \mathrm{C}$.

5. We found that the mean land surface temperature of the city parks was $12{ }^{\circ} \mathrm{C}$ below the mean temperature of intensive residential areas.

6. The low LST values of large parks did not effect the LST values of other land use areas around them. However this does not suggest, that the cooling effect of urban parks does not have effect on the air temperatures of the surrounding areas.

7. In the case of green roofs, surface temperatures were reduced by $3,5^{\circ} \mathrm{C}$. 


\section{Policy recommendations}

The conclusion of the research team is that in particular the LST primarily at manufacturing-logistic, commercial, intensive residential land uses and at railway and road junction areas should be reduced order to mitigate the negative effects of UHI, since these are the areas chiefly responsible for creating the UHI. Our recommendation is to reduce the LST at these areas by increasing the areas covered with vegetation within these land uses. These new green areas should be created on ground level but also on roofs as roof gardens or green roofs. The evaporation from vegetation acts like a natural air conditioning system and the foliage of the trees also has a positive shading effect. For these two reasons we suggest that the planting of deciduous trees, with large and highly evaporating foliage during the summer period, is the most effective way of reducing the UHI in Budapest, which is strongest in the summer. Obviously the increase of areas covered by vegetation is not the only way of reducing the UHI. However the aesthetic values of the plants is a very strong argument to support their use in urban environments.

Acknowledgements. First of all we would like the thank Richárd Ongjerth (Studio Metropolitana Research Director) for initiating, supervising and financing this research. We would like to thank Dr. Julia Martos (Budapest Corvinus University Mathematic Department) and Felix Pap (E-Build Ltd) for their kind help in the correlation and regression analysis. We would also like to thank Dr. János Mika and Péter Németh (National Meteorological Institute of Hungary) for providing us with the necessary meteorological data.

\section{REFERENCES}

[1] Bartholy, J., Pongrácz, R., Dezső, Zs. (2005): A hazai nagyvárosok hősziget hatásának elemzése finomfelbontású müholdképek alapján. (Analyzing the effect of UHI on major Cities in Hungary by satellite images) - AGRO-21 Füzetek 44: 32-44.

[2] Chang, C.R., Li, M.H., Chang, S.D. (2006): A preliminary study on the local cool-island intensity of Taipei city parks. - Landscape and Urban Planning, vol. 80(4): 386-395.

[3] Chen, X.L., Zhao, H.M., LI, P.X., Yin, Z.Y. (2006): Remote sensing image based analysis of the relationship between urban heat island and land use/cover changes Remote Sensing of Environment 104: 133-146.

[4] Gábor, P., Jombach, S., Ongjerth, R. (2006): Budapest zöldfelületi állapotfelmérése ürfelvételek feldolgozásával. (The analysis of biological active surfaces in Budapest utilizing satellite images) -Budapesti Corvnius Egyetem Tájépítészeti Kar, 4D Tájépítészeti és Kertmüvészet Folyóirat 4: 14-22.

[5] Gábor, P. (2007): Utilisation of Landsat images in surveying changes of biological activity in Budapest and its agglomeration 1990-2005. - MicroCAD 2007 International Scientific Conference, Miskolci Egyetem Innovációs és Technológia Transzfer Centruma, Miskolc: 57-62.

[6] Gallo, K.P., Owen, T.W. (1998): Satellite-based adjustments for the urban heat island temperature bias. - Journal of Applied Meteorology 38: 806-813.

[7] Gao, B.C. (1996): NDWI - a normalized difference water index for remote sensing of vegetation liquid water from space. - Remote Sensing of Environmen 58(3): 257-266.

[8] Gómez, F., Tamarit, N., Jabaloyes, J. (2001): Green zones, bioclimatics studies and human comfort in the future development of urban planning. - Landscape and Urban Planning 55: 151-161. 
[9] Gulyás Á., Unger J., Matzarakis, A. (2006): Assessment of the microclimatic and human comfort conditions in a complex urban environment: Modelling and measurements. Building And Environment 41: 1713-1722.

[10] Tran, H., Uchihama, D., Ochi, S., Yasuoka, Y. (2005): Assessment with satellite data of the urban heat island effects in Asian mega cities. - International Journal of Applied Earth Observation and Geoinformation 8(1): 34-48.

[11] Jimenez-Munoz, J.C., Sobrino, J.A. (2003): A generalized singlechannel method for retrieving land surface temperature from remote sensing data. - Journal of Geophysical Research 108. (doi: 10.1029/2003JD003480).

[12] Jombach, S. (2007): Landsat image utilization in green surface intensity survey of Budapest. - MicroCAD 2007 International Scientific Conference, Miskolci Egyetem Innovációs és Technológia Transzfer Centruma, Miskolc: 105-110.

[13] Jusuf, S.K.l., Wong, N.H., Hagen, E., Anggoro, R., Hong, Y. (2007): The influence of land use on the urban heat island in Singapore. - Habitat International 31(2): 232-242.

[14] Kim, Y.H., Baik, J.J. (2002): Maximum Urban Heat Island Intensity in Seoul. - Journal of Applied Meteorology 41: 651-653.

[15] Kolokotroni, M., Zhang, Y., Watkins, R. (2006): The London Heat Island and building cooling design. - Solar Energy 81(1): 102-110.

[16] Oke, T.R. (1987): Boundary layer climates $-\left(2^{\text {nd }}\right.$ ed.). London, Methuen

[17] Owen, T.W., Carlson, T.N., Gillies, R.R. (1998): An assessment of satellite remotelysensed land cover parameters in quantitatively describing the climatic effect of urbanization. - International Journal of Remote Sensing 19: 1663-1681.

[18] Qin, Z., Karnieli, A., Berliner, P. (2001): A mono-window algorithm for retrieving land surface temperature from Landsat TM data and its application to the Israel-Egypt border region. - International Journal of Remote Sensing 22(18): 3719-3746.

[19] Stathopoulou, M., Cartalis, C. (2006.): Daytime urban heat islands from Landsat ETM+ and Corine land cover data: An application to major cities in Greece. - Solgar Energy 81(3): 358-368.

[20] Sobrino, J.A., Jiménez-Munoz, J.C., Paolini, L. (2004): Land surface temperature retrieval from LANDSAT TM 5. - Remote Sensing of Environment 90: 434-440.

[21] Takebayashi, H., Moriyama, M. (2006.): Surface heat budget on green roof and high reflection roof for mitigation of urban heat island. - Building and Environment 42(8): 2971-2979.

[22] Wang, Y., Zhang, J., LI, Y. (2006): A C++ program for retrieving land surface temperature from the data of Landsat TM/ETM+ band6. - Computers \& Geosciences 32: 1796-1805.

[23] Weng, Q. (2001): A remote sensing-GIS evaluation of urban expansion and its impact on surface temperature in Zhujiang Delta, China. - International Journal of Remote Sensing 22(10): 1999-2014.

[24] Weng, Q., Lu, D., Schubring, J. (2004): Estimation of land surface temperaturevegetation abundance relationship for urban heat island studies. - Remote Sensing of Environment 89: 467-483.

[25] Zha, Y., Gao, J., Ni, S. (2003): Use of normalized difference built-up index in automatically mapping urban areas from TM imagery. - International Journal of Remote Sensing 24(3): 583-594.

[26] Zhong, B. (1996): Urban heat island effect of Shenzhen city. - Journal of Meteorology 22(5): $23-24$. 